Research Article

\title{
Modelling and Simulation of Gas Engines Using Aspen HYSYS
}

\author{
M. C. Ekwonu ${ }^{1,2^{*}}$, S. Perry ${ }^{1}$ and E. A. Oyedoh ${ }^{3}$ \\ ${ }^{1}$ Centre for Process Integration, School of Chemical Engineering and Analytical Science, University of Manchester, United Kingdom \\ ${ }^{2}$ Dep. of Chemical/Petroleum Engineering, Afe Babalola University, Ado-Ekiti, Nigeria \\ ${ }^{3}$ School of Chemistry and Chemical Engineering, Queen's University Belfast, Northern Ireland, United Kingdom
}

Received 15 July 2013; Accepted 10 December 2013

\begin{abstract}
In this paper gas engine model was developed in Aspen HYSYS V7.3 and validated with Waukesha 16V275GL+ gas engine. Fuel flexibility, fuel types and part load performance of the gas engine were investigated. The design variability revealed that the gas engine can operate on poor fuel with low lower heating value (LHV) such as landfill gas, sewage gas and biogas with biogas offering potential integration with bottoming cycles when compared to natural gas. The result of the gas engine simulation gave an efficiency $40.7 \%$ and power output of $3592 \mathrm{~kW}$.
\end{abstract}

Keywords: Modelling, Simulation, Gas engines, Waste heat recovery, Aspen HYSYS

\section{Introduction}

The International Energy Outlook 2011 [1] projects that world electricity demand will increase by 2.3 percent per year from 2008 to 2035 while the net electricity generation will rise by 84 percent from 19.1 trillion $\mathrm{kWh}$ in 2008 to 25.5 trillion $\mathrm{kWh}$ in 2020 and 35.2 trillion $\mathrm{kWh}$ in 2035. The energy required to power refrigeration system, including airconditioning systems and heat pumps represents $10-20 \%$ of the world total electricity consumption [2]. The rising cost of energy and emissions has necessitated the interest in an alternative economical, cost effective and least polluting means of power production [3]. Cogeneration and trigeneration have emerged as the solution to increase efficiency and reduce overall emissions in domestic and small-scale applications [4].

Combined cooling, heating and power (CCHP) also known as trigeneration, is a fast growing technology for efficient and clean production of energy. It can simultaneously generate mechanical power (often converted to electricity), heating and cooling from one primary source $[5,6]$. Waste heat recovery from CCHP systems offers an effective way of utilizing the energy of fuel efficiently, economically, reliably and with less harmful effects on the environment whilst improvement of the overall efficiency of the plant $[3,4,7,8]$.

Basically, trigeneration systems are CHP (combined heat and power) or cogeneration systems integrated with thermally driven refrigeration systems to provide cooling, electrical power and heating. [3, 6, 9-15]. The waste heat recovered from the power system and exhaust gases of a CCHP system can be utilized for heating and/or cooling applications using absorption chillers, adsorption chillers

\footnotetext{
* E-mail address: michael.ekwonu@gmail.com

ISSN: 1791-2377 @ 2011 Kavala Institute of Technology. All rights reserved.
}

and bottoming cycles [16]. Waste heat recovery allows more efficient use of fuel energy and reduces the cost of heat production [3]. Trigeneration has emerged as the solution to reduce overall emissions in domestic and small-scale applications whilst increasing the efficiency of the system. Therefore, trigeneration can be used for decentralized power generation and simultaneously provide cooling and heating demand for both domestic and industrial applications

In this study, gas engine modelling and simulation was carried out using Aspen HYSYS Sensitivity analysis on the gas engine model was carried out to study the effect of part load performance and the flexibility of the gas engine working on different fuel types and for potential integration with bottoming cycles for waste heat recovery and additional power generation whilst providing cooling and heating demands.

\section{Method of Simulation}

\section{Gas Engine Modelling}

Aspen HYSYS V7.3 simulator offers a comprehensive thermodynamics foundation for accurate calculation of physical properties, transport properties, and phase behaviour for the oil \& gas and refining industries. In this research, the fuel and working fluids are hydrocarbon mixtures; hence the Peng-Robinson (PR) fluid package is used as it has a robust database and equations which can generate better predictions of equilibrium for hydrocarbon systems [17].

The gas engine model configuration was developed first based on literature [18]. The gas engine model was validated using the Dresser Waukesha gas engine 16V275GL+ specification [19]. The compositions of the different types of fuel used are presented in 1. The gas engine configuration consists of a number of unit operations which include: material streams, an expander, 
compressors, mixers, coolers and a conversion reactor. A simple representation of the gas engine model is shown in Fig. 1. The Aspen HYSYS model of the gas engine is also shown in Fig. 2.

Tab. 1: Fuel compositions used for simulation $[19,21]$

\begin{tabular}{l|c|c|c|c|c}
\hline \multicolumn{1}{c|}{ Fuel type } & \multicolumn{2}{|c|}{ Natural gas } & \multicolumn{2}{c}{ Biogas } \\
\hline Composition & Base case & $\begin{array}{c}\text { Sample } \\
\mathbf{1}\end{array}$ & $\begin{array}{c}\text { Landfill } \\
\text { gas }\end{array}$ & $\begin{array}{c}\text { Sewage } \\
\text { gas }\end{array}$ & $\begin{array}{c}\text { Agrifood } \\
\text { industry }\end{array}$ \\
\hline Methane & 0.8856 & 0.8738 & 0.45 & 0.60 & 0.68 \\
Ethane & 0.0917 & 0.0474 & - & - & - \\
Propane & 0.0042 & 0.0254 & - & - & - \\
i-butane & - & 0.0119 & & & \\
n-butane & - & 0.0167 & & & \\
i-pentane & - & 0.0082 & & & \\
n-pentane & - & 0.0049 & & & \\
Hexane & - & 0.0026 & & & \\
Heptane & - & 0.0029 & & & \\
$\mathrm{CO}_{2}$ & 0.0065 & - & 0.35 & 0.33 & 0.26 \\
$\mathrm{~N}_{2}$ & 0.012 & 0.0013 & 0.20 & 0.01 & 0.01 \\
$\mathrm{H}_{2}$ & - & - & - & & - \\
$\mathrm{H}_{2} \mathrm{O}$ & - & - & - & 0.06 & 0.05 \\
$\mathrm{CO}^{\mathrm{O}_{2}}$ & - & - & - & - & - \\
\hline
\end{tabular}

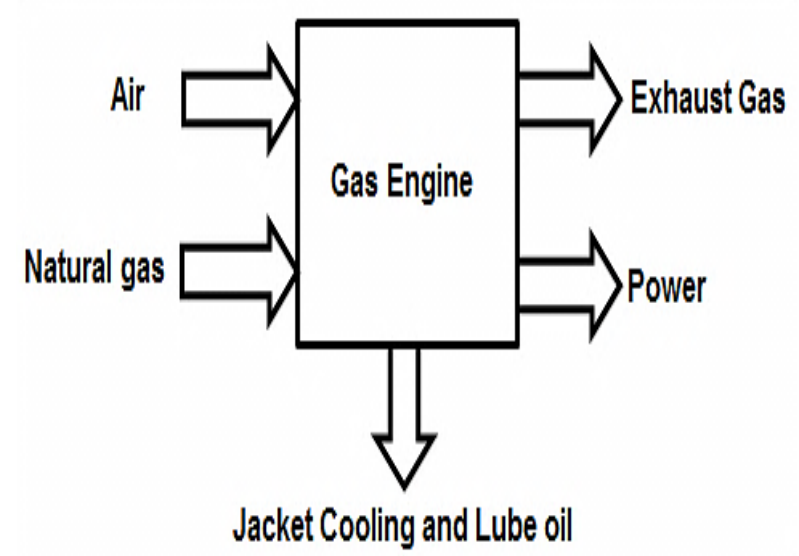

Fig. 1. A simple representation of gas engine

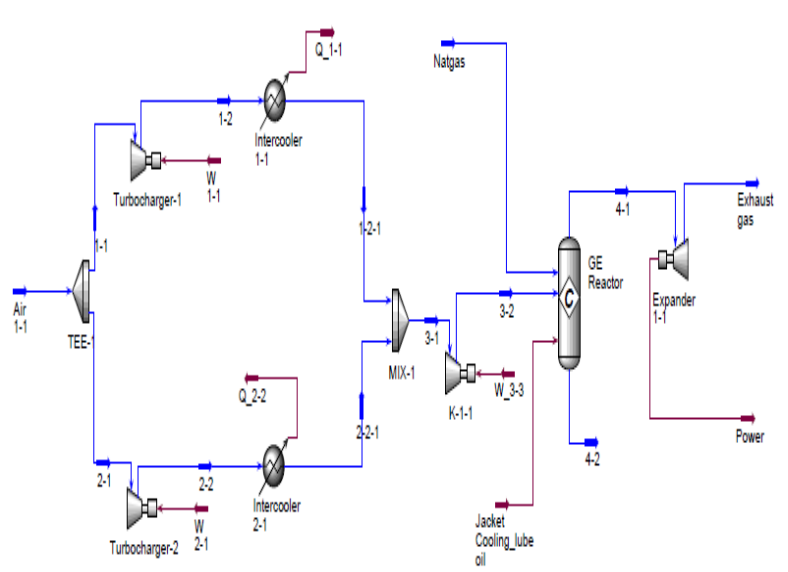

Fig. 2: Gas engine model in Aspen HYSYS

\section{Results and Discussion}

\section{Validation of model}

The gas engine model in Aspen HYSYS was validated using the Waukesha gas engine 16V275GL+ [19]. The output parameters obtained from Aspen HYSYS gas engine model was validated with the specifications from the manufacturer.
The result obtained from Aspen HYSYS simulation and specification values are presented in Error! Reference source not found. 2 .

Tab. 2: Validation of simulation results with Waukesha 16V275GL+ model

\begin{tabular}{l|c|c|c}
\hline Parameter & Specification & Simulation & Deviation (\%) \\
\hline $\begin{array}{l}\text { Power output (kW) } \\
\begin{array}{l}\text { Heat rejection to } \\
\text { intercooler (kW) }\end{array}\end{array}$ & 3605 & 3592 & -0.36 \\
$\begin{array}{l}\text { Heat rejection to Jacket } \\
\text { water and lube oil (kW) }\end{array}$ & 1181 & 887 & 0.00 \\
$\begin{array}{l}\text { Induction Air flow ( } \\
\left.\mathrm{Nm}^{3} / \mathrm{hr}\right)\end{array}$ & 18,691 & 18,691 & 0.00 \\
$\begin{array}{l}\text { Exhaust gas flowrate ( } \\
\mathrm{kg} / \mathrm{hr})\end{array}$ & 25,361 & 24,720 & -2.60 \\
$\begin{array}{l}\text { Exhaust stack } \\
\text { temperature }\left({ }^{\circ} \mathrm{C}\right)\end{array}$ & 433 & 436.2 & 0.74 \\
\hline
\end{tabular}

The deviation of the model from manufacturer's specification was minimal with the highest deviation of $2.60 \%$ in the exhaust gas flowrate specification (Error! Reference source not found.2). The simulated exhaust stack temperature was $436.2^{\circ} \mathrm{C}$ whilst a real gas engine that operates at $433^{\circ} \mathrm{C}$. This is explainable as Aspen HYSYS cannot give realistic variations of temperature of the fuel combustion process hence computational fluid dynamics (CFD) would be necessary. The power output obtained from simulation was $0.36 \%$ less than the real gas engine.

\section{Effect of ambient condition of inlet Air}

Fig. 3 show the effect of ambient air condition on the efficiency of the gas engine operated at lean burn condition. The efficiency decreases as the inlet air temperature increases. While this effect is significant on gas turbines, it is less significant on gas engines [20]. The engine efficiency decreases by $0.1 \%$ for every $10^{\circ} \mathrm{C}$ rise in ambient air temperature. Similar trend was observed for the output power of the gas engine.

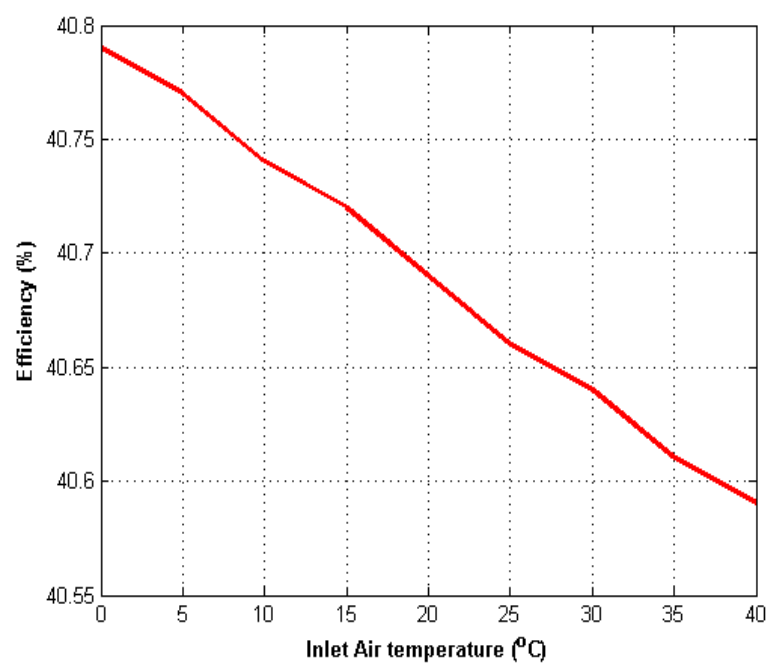

Fig. 3. Effect of ambient condition on efficiency

\section{Part load performance}

As the load of the gas engine is reduced, the heat rate of spark ignition engine increases while the efficiency drops. Fig. 4 show the part load efficiency curve for lean burn gas engine operated at fixed air-fuel ratio. The efficiency at $50 \%$ 
load was $8 \%$ less than full load, which was consistent with EPA report [20]. Gas engines exhibit a good part load performance compared to gas turbines which exhibits about $15-25 \%$ decrease in efficiency at part load [20]

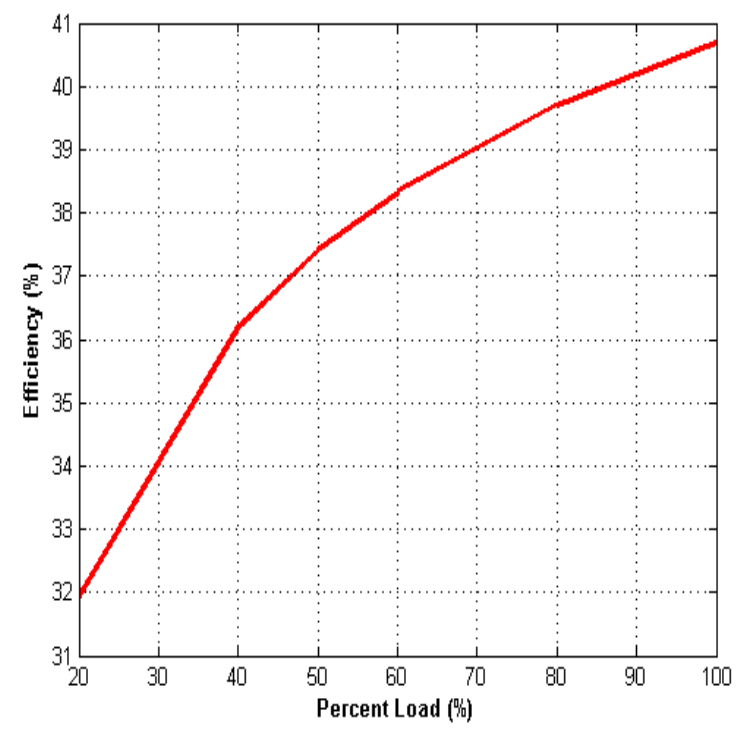

Fig. 4. Part load efficiency performance of gas engine

\section{Effect of different types of fuel}

The effect of the different types of fuel fed to the gas engine is presented in Error! Reference source not found.3. It can be seen that the base case and natural gas 1 had higher fuel heat content compared to landfill gas, biogas and sewage gas. The highest value was the base case at $8826 \mathrm{~kW}$ which was approximately four times that of landfill gas with the lowest value of $2360 \mathrm{~kW}$. This is explainable as the proportions of combustible components in landfill gas are much lower than other fuels. Landfill gas gave the lowest power output form the gas engine, which is owing to its fuel heat content. As a result, the efficiency and exhaust gas temperature showed similar trend. The lower heating value (LHV) of the different fuels also explains the observable trends in the power output, efficiency and exhaust temperature. Hence gas engines can operate on poor fuels such as landfill gas, sewage gas and biogas but integrating gas engines that operates on biogas with bottoming cycles can offer potential benefit compared to using landfill and sewage gas due to the exhaust temperatures as seen in Error! Reference source not found.3. It can be concluded that the power output, efficiency and exhaust temperature depends on the LHV of the fuel.

Tab. 3: Different types of fuel at fixed air-fuel ratio

\begin{tabular}{l|l|l|l|l|l}
\hline $\begin{array}{l}\text { Types of } \\
\text { fuel }\end{array}$ & $\begin{array}{l}\text { Fuel } \\
\text { heat } \\
\text { content, } \\
\mathbf{k W}\end{array}$ & $\begin{array}{l}\text { Output } \\
\text { power, } \\
\mathbf{k W}\end{array}$ & $\begin{array}{l}\text { Efficiency, } \\
\mathbf{\%}\end{array}$ & $\begin{array}{l}\text { Exhaust } \\
\text { temperature, } \\
{ }^{\circ} \mathbf{C}\end{array}$ & $\begin{array}{l}\mathbf{L H V}, \\
\mathbf{k g} / \mathbf{k J}\end{array}$ \\
\hline $\begin{array}{l}\text { Base case } \\
\text { Natural gas } \\
1\end{array}$ & 8826 & 3592 & 40.69 & 436.2 & 47850 \\
Landfill gas & 2360 & 544 & 23.03 & 5.8 & 44930 \\
Biogas & 4278 & 1462 & 34.18 & 122.6 & 12800 \\
Sewage gas & 3482 & 1072 & 30.78 & 66.3 & 23190 \\
\hline
\end{tabular}

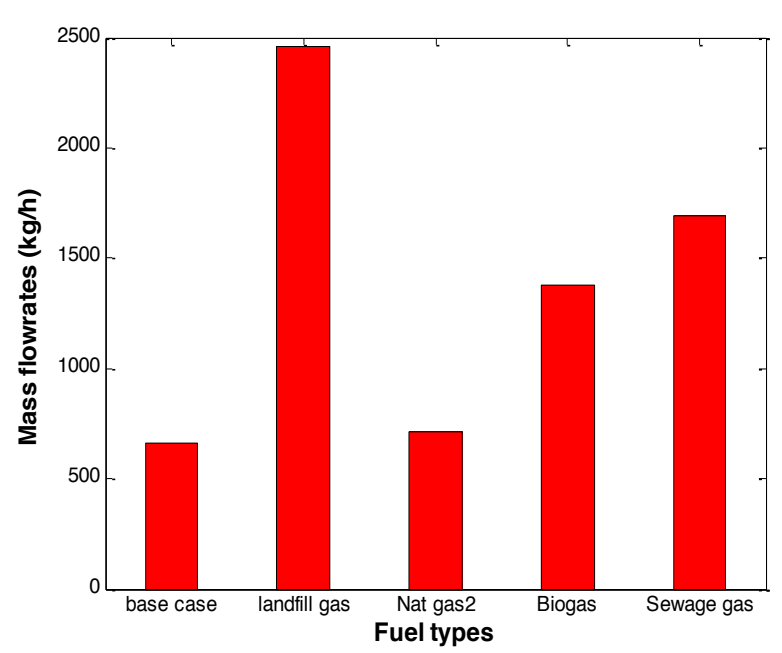

Fig. 5. Mass flow rate of different fuel at the fixed output power

The power output of the gas engine was fixed as specified $(3605 \mathrm{~kW})$ to determine the required amounts of fuel for different fuel types. From Fig. 5, landfill gas had the highest requirement of $2457 \mathrm{~kg} / \mathrm{h}$ which approximately four times that of the base case $(664 \mathrm{~kg} / \mathrm{h})$ and there was no significant difference between the base case and natural gas 1 .

\section{Effect of fuel flowrate}

Fig. 6 show the effect of fuel flowrate on the efficiency of the gas engine. As the fuel flowrate increases, the efficiency of the engine correspondingly increases. This can be attributed to the conversion of more chemical energy of the fuel into electrical energy [5]. Similar trend was observed for the power output and exhaust gas temperature, although in both cases a linear relationship was observed.

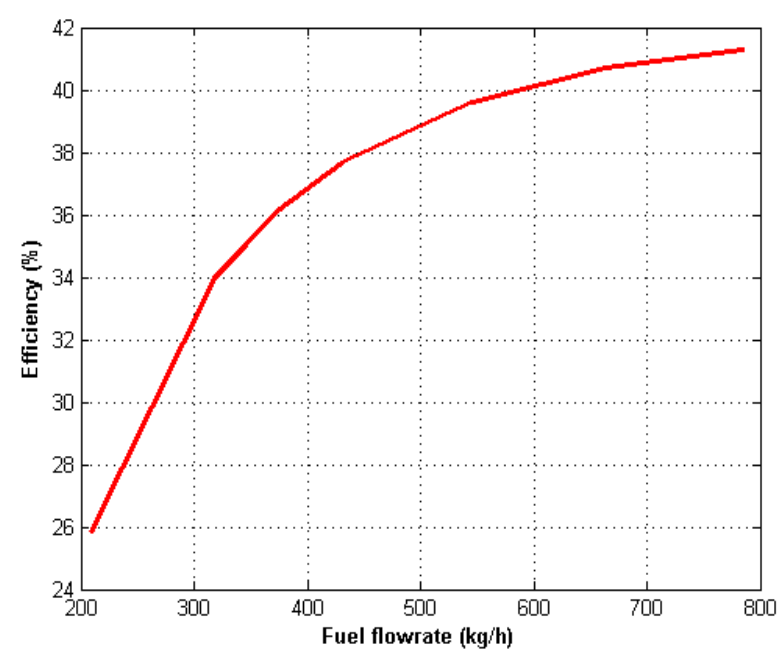

Fig. 6. Effect of fuel flowrate on the efficiency of the gas engine

\section{Conclusion}

Aspen HYSYS simulation gave close representation of the real gas engine.

- The part performance analysis showed that gas engines exhibit a better performance at $50 \%$ load compared to gas turbines. The efficiency at $50 \%$ load was $8 \%$ less than at full load suggesting that gas engines are 
suitable for use where fluctuations in load are experienced.

- The design variability of the gas engine model with different fuel types gave interesting results, showing the flexibility of the gas engine in terms of the choice of fuel without additional treatment. Moreover, low- grade fuels that have low heating values such as landfill gas; sewage gas and biogas can be used. This was demonstrated by the fact that although natural gas had almost three times lower heating value than sewage gas, the gas engine can operate on sewage gas as fuel input without requiring further treatment.

\section{References}

1. IEO International Energy Outlook. 2011.

2. Trygg, L. and S. Amiri, European perspective on absorption cooling in a combined heat and power system - A case study of energy utility and industries in Sweden. Applied Energy, 2007. 84(12): p. 1319-1337.

3. Lai, S.M. and C.W. Hui, Feasibility and flexibility for a trigeneration system. Energy, 2009. 34(10): p. 1693-1704.

4. Angrisani, G., et al., Experimental results of a micro-trigeneration installation. Applied Thermal Engineering, 2012. 38(0): p. 78-90.

5. Ma, S., et al., Thermodynamic analysis of a new combined cooling, heat and power system driven by solid oxide fuel cell based on ammonia-water mixture. Journal of Power Sources, 2011. 196(20): p. 8463-8471.

6. Malico, I., A.P. Carvalhinho, and J. Tenreiro. Design of a trigeneration system using a high-temperature fuel cell. in International Journal of Energy Research. 2009. Southern Gate, Chichester, West Sussex, PO19 8SQ, United Kingdom: John Wiley and Sons Ltd.

7. Kavvadias, K.C., A.P. Tosios, and Z.B. Maroulis, Design of a combined heating, cooling and power system: Sizing, operation strategy selection and parametric analysis. Energy Conversion and Management, 2010. 51(4): p. 833-845.

8. Al-Sulaiman, F.A., I. Dincer, and F. Hamdullahpur, Exergy analysis of an integrated solid oxide fuel cell and organic Rankine cycle for cooling, heating and power production. Journal of Power Sources, 2010. 195(8): p. 2346-2354.

9. Martin, J.I.S., et al. Trigeneration Systems with Fuel Cells. 2012.

10. Lin, L., et al., An experimental investigation of a household size trigeneration. Applied Thermal Engineering, 2007. 27(2-3): p. 576-585.

11. Al-Sulaiman, F.A., F. Hamdullahpur, and I. Dincer, Performance comparison of three trigeneration systems using organic rankine cycles. Energy, 2011. 36(9): p. 5741-5754.
12. Deng, J., R.Z. Wang, and G.Y. Han, A review of thermally activated cooling technologies for combined cooling, heating and power systems. Progress in Energy and Combustion Science, 2011. 37(2): p. 172-203.

13. Ziher, D. and A. Poredos, Economics of a trigeneration system in a hospital. Applied Thermal Engineering, 2006. 26(7): p. 680-687.

14. Mago, P.J., N. Fumo, and L.M. Chamra, Performance analysis of CCHP and CHP systems operating following the thermal and electric load. International Journal of Energy Research, 2009. 33(9): p. 852-864.

15. Amid, P., F. Saffaraval, and M. Saffar-avval, Feasibility study of different scenarios of CCHP for a residential complex, in Innovative Technologies for an Efficient and Reliable Electricity Supply (CITRES). 2010. p. 177-183.

16. Kong, X.Q., et al., Experimental investigation of a micro-combined cooling, heating and power system driven by a gas engine. International Journal of Refrigeration, 2005. 28(7): p. 977-987.

17. Aspen Technology Inc., 2012.

18. Rutherford, J.P., Heat and Power Applications of Advanced Biomass Gasifiers in New Zealand's Wood Industry A Chemical Equilibrium Model and Economic Feasibility Assessment. 2006, University of Canterbury. Chemical and Process Engineering.

19. GE Energy. Waukesha gas engines 275GL. 2012 [cited 201224 July,]; Available from: http://www.dresserwaukesha.com/documents/7116_1011_16V275 GLplus_specsheet.pdf.

20. EPA. Technology Characterization: Reciprocating Engines. 2012; Available from: http://www.epa.gov/chp/documents/catalog_chptech_reciprocating engines.pdf.

21. Waste gas composition. 2012 [cited 201216 August]; Available from:

http://www.arb.ca.gov/energy/dg/meetings/01132005/wastegascom position.pdf. 